\title{
Mosque Energy Performance, Part I: Energy Audit and Use Trends Based on the Analysis of Utility Billing Data
}

\author{
AbDou, A. A., Al-Homoud, M. S., AND Budaiwi, I. M. \\ Architectural Engineering Department \\ KFUPM, Dhahran, Saudi Arabia \\ adel@kfupm.edu.sa
}

\begin{abstract}
Mosques are distinguished from other types of buildings by having a unique function characterized by an intermittent operation schedule. Within a given area and time zone, mosques are operated simultaneously, which could have an impact on the demand for energy particularly in areas that are highly dependent on mechanical airconditioning, and/or heating for achieving thermal comfort. The importance of achieving thermal comfort in mosques to enable worshippers perform prayers in a spiritual environment with minimum energy requirements; make the thermal design and operation of energy systems in mosques critical parameters in determining their performance. The analysis of electric energy bills data is a feasible and useful approach in showing the general trend and the history of energy use. The billing data can provide a reasonable estimate of the overall annual electric energy use in mosques. This study presents the analysis of five-year electric energy billing data for five typical mosques in the hot-humid climate of the eastern region of Saudi Arabia. The aim is to assess and compare energy use trends over time of different types of mosques as a step towards a comprehensive study of their energy systems, overall thermal performance and operation strategies.
\end{abstract}

KEYwORDS: Energy audit, mosques, energy use, utility bills.

\section{Introduction}

In harsh climatic regions, mosques have to be mechanically air-conditioned to achieve the required thermal comfort for worshippers. Mosques are characterized by having a unique operation schedule as compared to other types of buildings. They are usually occupied five intermittent times a day all year 
round with each occupancy averaging from a fraction of an hour to an hour. People do not usually arrive at or leave the mosque at exactly the same time during this hour but rather at random and therefore maximum occupancy is expected to occur during the actual performance of each prayer which lasts from about 15 to 20 minutes. Some exceptions to this pattern of use are weekly (Friday) prayer and Taraweeh prayer during the nights of the month of Ramadan as well as during other special occasions such as lecturing and seminar activities where people tend to stay longer in the mosque.

\subsection{Energy Requirements}

In Saudi Arabia, consumption by energy systems of buildings accounts for a major share of energy demand, exceeding $70 \%$ of total electric energy use in the kingdom for the year 2002 [1]. In contrast, industrial consumption of electric energy was about $25 \%$ for the same year. This includes the eastern region of the Kingdom where major industrial consumers such as Saudi ARAMCO and SABIC are located. For other regions of the Kingdom the share of buildings in electric energy consumption could reach more than $90 \%$. The use of energy in mosques lies within the $16.2 \%$ average consumed by government buildings in the Kingdom. The demand for energy in mosques is critical as they are operated almost at the same time of the day in each region especially at the times of Duhr (noon) and Asr (afternoon) prayers which fall within the most critical demand periods in summer. In spite of the high demand, however, the required thermal comfort is not necessarily achieved, due to improper operation of the airconditioning systems where under/overcooling are frequently practiced in many mosques and this may greatly impact on the spiritual experience and physical comfort status of worshippers.

Mosques are of great importance to Muslim communities and therefore require in-depth research and analysis of their thermal design and energy performance. A search of the literature indicates that there is a lack of research on energy in mosques. However, many studies have been conducted on energy conservation in other types of buildings. For example, Said and Abdelrahman [2] conducted a parametric energy analysis on a detached single-family house in Dhahran using DOE 2.1. The study showed potentials for reducing energy consumption in residential buildings if the buildings and systems are properly designed and operated. Parameters with the greatest impact are glazed areas, infiltration level, walls, and roof construction, in addition to the behavioral parameter of thermostat settings. As much as $38 \%$ reduction in the total annual energy consumption was reported from the study considering the combined effect of the analyzed parameters. Other studies on envelope optimum thermal design of residential and office buildings in hot and hot-humid climates of Saudi Arabia have also been conducted [3,4]. Annual energy savings of as 
much as $37 \%$ and $28 \%$ were achieved in the optimization of small two-story residential buildings in the two climates of Riyadh and Jeddah cities, respectively. Various annual energy savings were achieved through envelope thermal design optimization of large, medium, and small office buildings in the two climates with as much as $15 \%, 19 \%$ and $40 \%$ savings for the three office sizes respectively, in Riyadh compared to about $8 \%, 12 \%$, and $24 \%$ for the same offices in Jeddah. [3, 4]

Proper design and operation of mosques can reduce the reliance upon supplemental mechanical heating and air-conditioning systems to achieve thermal comfort. The requirements for such systems depend on the function and operation schedule, as well as the climate that influences the thermal performance of the building and its design. The function and operating schedule of the mosque are operational parameters over which architectural designers have little control. The features, which suit the climate, however, can only be incorporated by the designer through proper selection and integration of the physical components of the building right through the design process.

Compared to research on thermal performance and operation of energy systems in buildings used for other functions, thermal performance and energy use in mosques have surely been neglected by researchers. For example, the limited research work that has been reported in literature on mosque thermal design, operation and energy use further support the need to develop a comprehensive knowledge particularly with reference to mosques in Saudi Arabia, where a large number are being operated and newly constructed, and where, in many parts of the Kingdom, climatic conditions necessitate total reliance on mechanical air-conditioning systems most of the year. As a first step, it is necessary to assess and compare energy use trends over time in different types of mosques. This study constitutes part I of a comprehensive investigation of mosque energy systems, overall thermal performance and operation strategies. This part ponders and presents the analysis of five-year electric energy billing data for a representative sample of typical mosques in the hot-humid climate of the eastern region of Saudi Arabia.

\subsection{Classification of Mosque Types}

Since the construction of the first mosque, by Prophet Mohammed (PBUH), the multi-function nature of the mosque has remained unchanged. However, the mosque architectural form, space, construction systems, and building materials have evolved and developed greatly, mainly as a result of regional, cultural and climatic differences. However, recent developments in active environmental control systems (e.g. air-conditioning) have also positively and/or negatively contributed to the contemporary architecture of mosques. 
Contemporary mosques may be also broadly classified, according to their sizes and locations [5, 6], as: 1. Larger Mosques located in large cities as public landmarks. These mosques are usually built by the government as an expression of the state's commitment to Islam. They are generally grand in size and of large congregation capacity. 2. Community Mosques ("Jamma" Mosques) distributed in urban and rural Muslim settlements, and are sometimes intended to house multiple functions (libraries, schools, meeting rooms, clinics, etc.) in addition to the prime function of a space for prayer. They are usually utilized for both Daily as well as Friday prayers and occasionally are supplemented with a separate annex on the same floor level or in a mezzanine for female worshippers. 3. Small local Mosques located in small neighborhoods.

Mosques in Saudi Arabia can be also classified broadly into a further two major categories. These are designed and built by the Ministry of Islamic Affairs, Endowments, Da wah and Guidance (MIAEDG) and those designed and built by private donors. The first of these categories of mosques is standardized into various sizes ranging from small and medium, to the large type of mosque. They have similar characteristics in terms of layout, shape and construction materials, as well as the type of air-conditioning and other energy systems used. The privately donated mosques do not usually follow a specific standard in their design or construction. Some of them are donated to the ministry after construction, for operation and maintenance, while others continue to be operated and maintained by the donor under the supervision of the ministry. The planning standards for these types of mosque in Saudi Arabia exist [6]. Due to the harsh climatic conditions in most parts of Saudi Arabia, active air-conditioning is necessary in operating mosques. Therefore, most mosques are equipped with a central, split, window or combination type unit of air-conditioning system, in conjunction with ceiling fans.

Due to the diversity of mosque types with respect to their size and type of construction, it was found necessary to limit this study to those mosques designed by the MIAEDG. These mosques were surveyed to assess their actual conditions, and subsequently criteria were set for selecting representative sample mosques for detailed energy audit. For that purpose, a list of mosques located in the eastern region of Saudi Arabia was obtained from the MIAEDG [7]. This list included mosques built by the ministry as well as those built by private donors. Exclusion of the latter group resulted in a total of 156 candidate mosques. Sets of design drawings for some typical mosques were also obtained for preliminary review and assessment of the major common characteristics and systems to be considered in developing an appropriate energy audit form. 


\section{Mosque Energy Audit}

Energy audit is a necessary process to identify and quantify energy and cost savings that can be achieved through investment in energy conservation measures. "The energy audit serves to identify all of the energy streams into a facility and to quantify energy use according to discrete functions" [8, pp.1-2]. A systematic approach to energy audit in mosques was developed to provide an accurate and practical account of energy consumption and performance in mosques [9]. The approach offers a step-by-step procedure that takes into account the diversity of mosque types, the uniqueness of mosque design and energy system types and operation.

In order to collect relevant information from mosques during field surveys, a special energy audit form was developed. The information collected for each mosque was classified in the following major categories: general information; surroundings; mosque physical data; zoning; construction information; window system; lighting system; A/C system; air circulation system; hot water system; power supply; and an area for additional comments. A preliminary audit form was developed and used in a pilot survey in a sample mosque. The objective was to test the appropriateness of the form contents, the ease of its use and how it is interpreted by each member in the survey team. The form was then revised by clarifying certain items, deleting redundant items and adding additional information required. The final revised audit form shown in Fig. 1 was then used to conduct the field surveys. Out of the 156 mosques, a total of 132 mosques were located and surveyed employing the developed audit form. The remaining 24 mosques were either not located or found to be not typical or useful for the purpose of this investigation. Subsequently a database was developed for the purpose of storing all collected information electronically for further processing and retrieval of required data in the desired form. This was also meant to help in the selection of representative sample mosques for detailed monitoring and/or simulation.

\subsection{Selection Criteria for Representative Sample Mosques}

Considering the number of surveyed mosques, the time and equipment required, it would have been impractical to carry out detailed energy investigations for all surveyed mosques. Instead, representative sample mosques had to be selected based on specific criteria that took into account in a practical way the diversity of the surveyed mosques without affecting the credibility of the research findings. The selected sample mosques had to be typical and reflect the most common types built in terms of capacity, construction, shape, and type of air-conditioning system with minimum deviations from the original design. The comprehensive mosque information compiled and stored in the database 
was utilized to categorize mosques according to their capacity, aspect ratio and type of air-conditioning system. In order to select a representative sample of mosques, a two-phase procedure was utilized. In the first phase, mosques were grouped according to capacity into six main groups as summarized in Fig. 2.

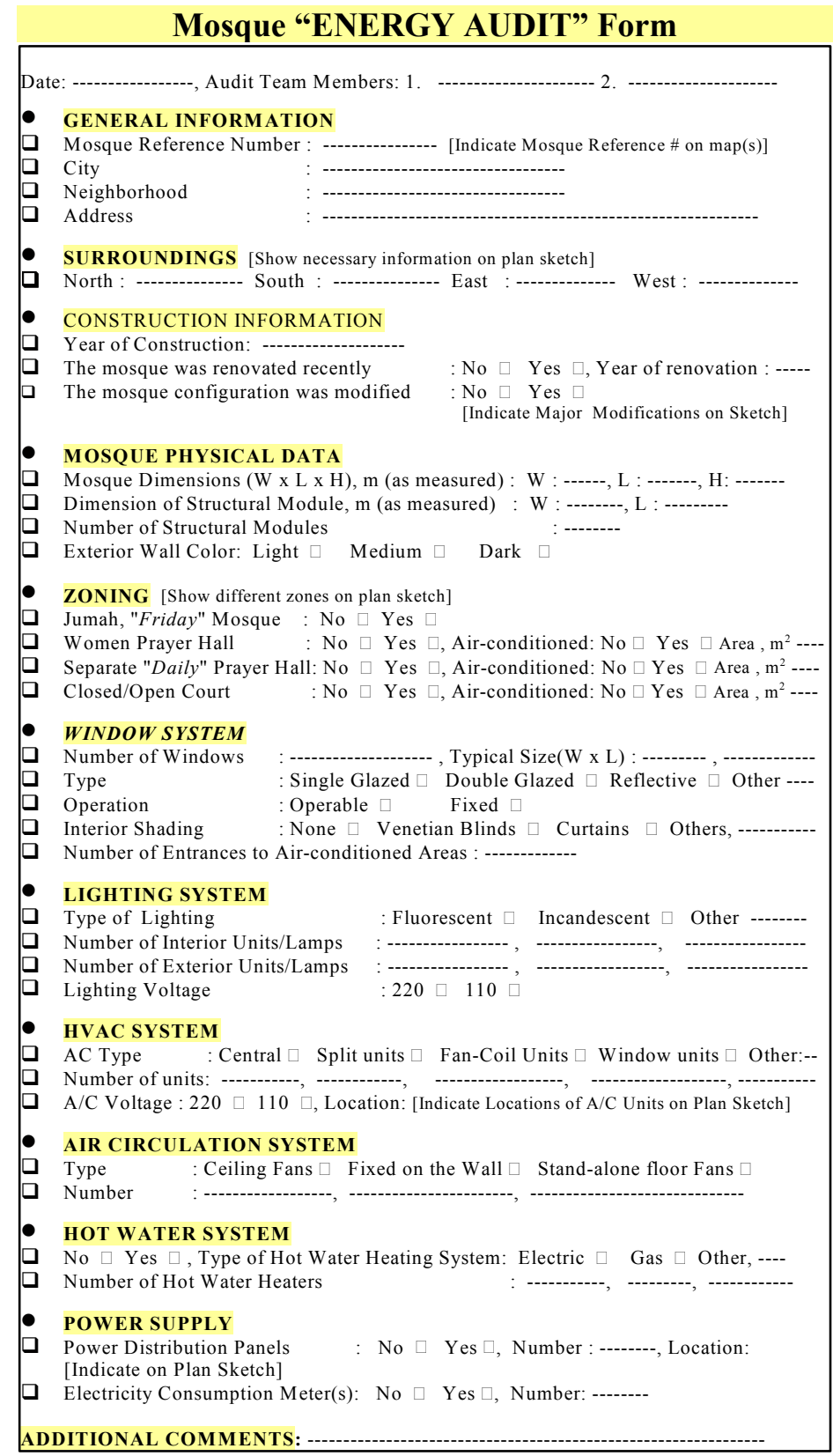

Fig. 1: Major and sub-components of the mosque energy audit form 


\begin{tabular}{|c|c|c|}
\hline Group & $\begin{array}{c}\text { Mosque } \\
\text { Capacity }\end{array}$ & $\begin{array}{c}\text { No. of } \\
\text { Mosques }\end{array}$ \\
\hline I & $<=250$ & 60 \\
\hline II & $251-500$ & 42 \\
\hline III & $501-750$ & 10 \\
\hline IV & $751-1000$ & 10 \\
\hline V & $1001-1750$ & 7 \\
\hline VI & $>1750$ & 3 \\
\hline & TOTAL & $\mathbf{1 3 2}$ \\
\hline
\end{tabular}

(a)

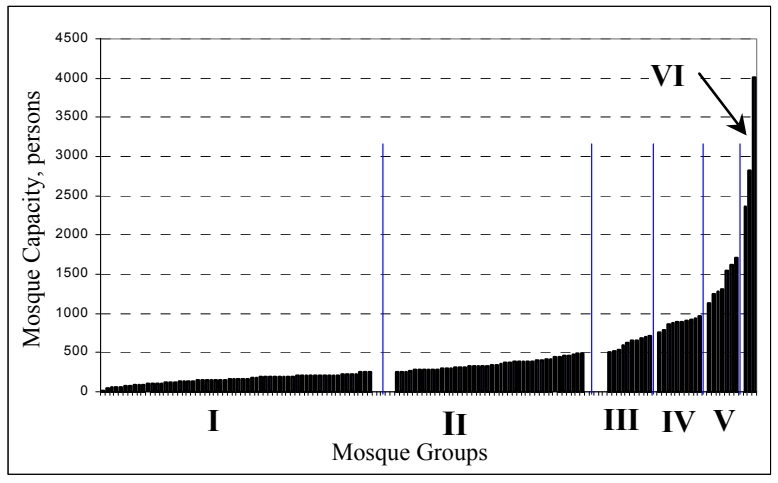

(b)

Fig. 2: (a) Summary of the surveyed mosque groups classified by capacity, and (b) The capacity distribution of the 132 mosques.

The objective was to select a number of mosques from each group proportional to the total number in each category. In the second phase, a twostep elimination process was utilized to further reduce the list of candidate mosques for detailed energy monitoring and analysis based on the following criteria:

a. Location (i.e. mosques located close to the Dhahran area were preferred for easy access and close monitoring by the project team members); and

b. Amount and cost of required energy monitoring equipment.

In the first step of the elimination process, the convenience of monitoring and collecting data and the cost of the energy audit/monitoring process were considered in reducing the number of mosques in the target sample. Based on the above criteria the number of mosques in each of the six groups of the list was further reduced as shown in Table 1 by excluding mosques located far from the Dhahran area. In the second step of the elimination process the number of mosques was further reduced considering the following criteria:

a. Uniformity of the air-conditioning $(\mathrm{A} / \mathrm{C})$ system;

b. Degree of deviation from original design; and

c. Accessibility and degree of surrounding obstructions.

The database revealed that some mosques have two or more different $\mathrm{A} / \mathrm{C}$ systems. According to the second set of criteria, mosques with minimum diversity in terms of $\mathrm{A} / \mathrm{C}$ system types were selected and considered more appropriate for further energy simulation as they represented a more normal trend in $\mathrm{A} / \mathrm{C}$ design and offered a better opportunity for more reliable correlation between energy consumption and $\mathrm{A} / \mathrm{C}$ system type and operation 
strategy. Accordingly, it was then decided to select at least one mosque from each group for detailed study. A number of mosques were selected for site visits in order to confirm their suitability to the study according to the above set criteria. As a result, some mosques were observed to have been subjected to major construction changes compared to the original design and were excluded since they lacked the characteristic of being typical and would present a major challenge when performing energy simulation due to difficulty in obtaining relevant information. Also, mosques in which energy systems were highly diversified or control systems were not well placed or randomly connected to the power supply lines were also excluded. Based on the consideration of the second set of criteria, five mosques were selected for in-depth energy monitoring and analysis. The characteristics of the selected mosques are summarized in Table 1. The subsequent activities involved acquiring energy use histories (i.e. electric energy bills) and details of the physical characteristics of these mosques for the purpose of detailed investigations.

Table 1: Summary of the main characteristics of the selected sample mosques.

\begin{tabular}{|c|c|c|c|c|c|c|}
\hline \multicolumn{2}{|c|}{ Mosque } & \multirow[b]{2}{*}{$\begin{array}{l}\text { Capacity } \\
\text { (Persons) }\end{array}$} & \multirow{2}{*}{$\begin{array}{c}\text { Average } \\
\text { Occupancy } \\
(\%)\end{array}$} & \multirow[b]{2}{*}{ Construction } & \multirow{2}{*}{\multicolumn{2}{|c|}{$\begin{array}{c}\text { Air- } \\
\text { Conditioning } \\
\text { System Type } \\
\& \\
\text { Operation }\end{array}$}} \\
\hline $\begin{array}{c}\text { Name } \\
\& \\
\text { Location } \\
\end{array}$ & Type & & & & & \\
\hline $\begin{array}{l}\text { Al-Humaidi } \\
\text { Al-Thuqbah }\end{array}$ & Daily & 190 & $100 \%$ & \multirow{4}{*}{$\begin{array}{l}\text { Un-insulated } \\
\text { Concrete } \\
\text { Masonry } \\
\text { Block } \\
\text { (CMU) } \\
\text { plastered }\end{array}$} & Window & \multirow{5}{*}{ 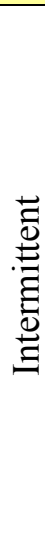 } \\
\hline $\begin{array}{l}\text { Owais Al-Qarni } \\
\text { Dammam }\end{array}$ & Daily & 391 & $30 \%$ & & $\begin{array}{l}\text { Window } \\
\text { and } \\
\text { floor- } \\
\text { mounted }\end{array}$ & \\
\hline $\begin{array}{l}\text { Al-Bukhari } \\
\text { Al-Khobar }\end{array}$ & $\begin{array}{l}\text { Daily/ } \\
\text { Friday }\end{array}$ & 723 & $\begin{array}{c}30 \% \\
100 \%\end{array}$ & & Window & \\
\hline $\begin{array}{l}\text { Al-Doha } \\
\text { Dhahran }\end{array}$ & $\begin{array}{l}\text { Daily/ } \\
\text { Friday }\end{array}$ & 890 & $\begin{array}{c}30 \% \\
100 \%\end{array}$ & & $\begin{array}{l}\text { Window } \\
\text { and } \\
\text { packaged } \\
\text { units }\end{array}$ & \\
\hline $\begin{array}{l}\text { Abu-Ubaidah } \\
\text { Al-Thuqbah }\end{array}$ & $\begin{array}{l}\text { Daily/ } \\
\text { Friday }\end{array}$ & 1319 & $\begin{array}{c}30 \% \\
100 \%\end{array}$ & $\begin{array}{c}\text { Insulated } \\
\text { concrete block } \\
\text { plastered }\end{array}$ & Split units & \\
\hline
\end{tabular}

\section{Analysis of Electric Energy Billing Data of Mosques}

Electric utility bills can provide useful information about the overall energy performance of the building and help in assessing the history of electric energy use and in finding out the pattern and consistency or otherwise of use in the investigated mosques. The electric energy use data for the five years (1999- 
2003 G, 1419-1423 H) was obtained from the Saudi Electric Company-East for the investigated mosques. However, some difficulties were encountered in using the data. First, readings for some months were not reported separately for those months but were rather accumulated in the reported reading of the subsequent month. Second, the use of Lunar months (Hijri calendar) as the basis for reporting energy use data and the corresponding variations in the bills reporting periods from year to year made it difficult to match billing data with seasonal variations (weather dependency) over the years. Third, the inconsistency in reporting the data both in terms of the frequency of taking the actual readings every month as well as in terms of the time of the month at which readings were taken. In view of the above difficulties, the data was analyzed as follows:

1. Missing monthly records were estimated from the accumulated record reported in the subsequent month in a weighted average manner. The missing values were interpolated from the records of the same month(s) in the preceding and the succeeding years proportional to the weight of energy use for that month record from the total of the accumulated reported reading. Table 2 shows sample monthly electric energy utility data for Owais AlQarni mosque with the missing data records highlighted for several months. The estimated records of the missing readings for this mosque were calculated in a weighted average manner as indicated above and are shown in the last column of Table 3. The same approach was followed in estimating all missing records for all mosques.

2. Annual energy use for each mosque was converted into annual energy use index per unit area $\left(\mathrm{kWh} / \mathrm{m}^{2} . \mathrm{yr}\right)$ in order to compare with other mosques on a unit area basis regardless of mosque size. The five-year monthly and annual electric energy use and indices for the investigated mosques are shown in Table 4. Monthly energy use indices for the five mosques averaged over five-year billing data (1999-2003, 1419-1423 H) are shown in Fig. 3 along with the average annual profile (highlighted in bold). Assessment of the resulting curves shows the same general trend in annual energy use per unit area for all mosques with some variations from one year to another. These variations can be attributed to many factors, notable among them being the variations in weather conditions from one year to another in addition to differences in operating patterns of energy systems in those mosques. 
Table 2: Example electric energy utility bill data for Owais Al-Qarni mosque as obtained from the Saudi Electric Company-East

\begin{tabular}{|c|c|c|c|c|c|c|c|c|}
\hline & & \multicolumn{7}{|c|}{ Years ( H ) } \\
\hline & Month & 1417 & 1418 & 1419 & 1420 & 1421 & 1422 & 1423 \\
\hline 1 & Moharram & 2160 & 960 & 3120 & 1680 & 5280 & 1360 & 1440 \\
\hline 2 & Safar & 12560 & 7360 & 4960 & 7840 & 5520 & 6560 & 3520 \\
\hline 3 & Rabi Awal & 7360 & 15360 & 12480 & 8960 & 6720 & 4480 & 4480 \\
\hline 4 & Rabi Akhir & 14880 & 6800 & 11680 & $?$ & 7680 & 10080 & 10800 \\
\hline 5 & Jamad Awal & 8160 & 6880 & 15200 & $?$ & 15440 & 6480 & 9440 \\
\hline 6 & Jamad Akhir & 4560 & 8640 & 9280 & 35760 & 14800 & 10160 & 4720 \\
\hline 7 & Rajab & 2480 & 5520 & 4560 & ? & ? & 11360 & 14560 \\
\hline 8 & Shaban & 1120 & 720 & 3040 & ? & 10460 & 3600 & 9200 \\
\hline 9 & Ramdan & 1440 & 1360 & 800 & 16480 & 320 & 4480 & 4720 \\
\hline 10 & Shawal & 2080 & 2800 & 2400 & 1280 & 2560 & 3200 & 3600 \\
\hline 11 & Zul-Qidah & 1840 & 800 & 1440 & 3360 & 1600 & 1600 & 1680 \\
\hline 12 & Zul- Hijjah & 2800 & 1520 & 1280 & 1680 & 1760 & 2320 & 1440 \\
\hline
\end{tabular}

Table 3: Illustrative example showing the process utilized for estimating the missing monthly electric energy bill data records. (i.e. within the highlighted box shown in Table 2)

\begin{tabular}{|c|c|c|c|c|c|c|}
\hline & 1419 & 1420 & 1421 & & \multirow[b]{2}{*}{$\%$ average } & \\
\hline$\% \mathrm{TOT}_{3}$ & Given & & Given & $\% \mathrm{TOT}_{3}$ & & \\
\hline 0.32 & 11680 & $?$ & 7680 & 0.20 & 0.26 & 9397 \\
\hline 0.42 & 15200 & ? & 15440 & 0.41 & 0.41 & $\rightarrow 14796$ \\
\hline 0.26 & 9280 & $?$ & 14800 & 0.39 & $0.32-$ & $\rightarrow 11567$ \\
\hline-1.00 & 36160 & 35760 & 37920 & 1.00 & 1.00 & 35760 \\
\hline
\end{tabular}

Table 4: Five-year (H) monthly and total electric energy use and indices for the five sample mosques

\begin{tabular}{|c|c|c|c|c|c|c|c|c|c|c|c|}
\hline \multirow[b]{3}{*}{ \# } & \multirow[b]{3}{*}{ Month } & \multicolumn{10}{|c|}{ 5-year (H) Average } \\
\hline & & \multicolumn{2}{|c|}{ Owais Al-Qarni } & \multicolumn{2}{|c|}{ Al-Humaidi } & \multicolumn{2}{|c|}{ Al-Bukhari } & \multicolumn{2}{|c|}{ Abu-Ubaidah } & \multicolumn{2}{|c|}{ Al-Doha } \\
\hline & & $\mathrm{kWh}$ & $\mathrm{kWh} / \mathrm{m}^{2}$ & kWh & $\mathrm{kWh} / \mathrm{m}^{2}$ & kWh & $\mathrm{kWh} / \mathrm{m}^{2}$ & kWh & $\mathrm{kWh} / \mathrm{m}^{2}$ & kWh & $\mathrm{kWh} / \mathrm{m}^{2}$ \\
\hline 1 & Moharram & 2576 & 6.9 & 1066 & 5.9 & 4656 & 6.7 & 2683 & 2.1 & 5550 & 6.5 \\
\hline 2 & Safar & 5680 & 15.1 & 2698 & 14.8 & 9248 & 13.3 & 6344 & 5.0 & 9990 & 11.7 \\
\hline 3 & Rabi Awal & 7424 & 19.8 & 3999 & 22.0 & 12440 & 17.9 & 10380 & 8.2 & 16350 & 19.1 \\
\hline 4 & Rabi Akhir & 9927 & 26.5 & 4499 & 24.7 & 15129 & 21.8 & 13317 & 10.5 & 20826 & 24.4 \\
\hline 5 & Jamad Awal & 12271 & 32.7 & 4805 & 26.4 & 16328 & 23.5 & 16763 & 13.2 & 25346 & 29.7 \\
\hline 6 & Jamad Akhir & 10105 & 26.9 & 4941 & 27.1 & 16959 & 24.4 & 16670 & 13.2 & 23758 & 27.8 \\
\hline 7 & Rajab & 9794 & 26.1 & 4728 & 26.0 & 17889 & 25.8 & 13933 & 11.0 & 24072 & 28.2 \\
\hline 8 & Shaban & 4653 & 12.4 & 3083 & 16.9 & 9859 & 14.2 & 9585 & 7.6 & 12427 & 14.6 \\
\hline 9 & Ramdan & 2270 & 6.1 & 1738 & 9.5 & 7020 & 10.1 & 6647 & 5.3 & 7721 & 9.0 \\
\hline 10 & Shawal & 2608 & 7.0 & 1749 & 9.6 & 6416 & 9.2 & 5820 & 4.6 & 8310 & 9.7 \\
\hline 11 & Zul-Qidah & 1936 & 5.2 & 816 & 4.5 & 2480 & 3.6 & 2430 & 1.9 & 4740 & 5.6 \\
\hline \multirow[t]{3}{*}{12} & Zul- Hijjah & 1696 & 4.5 & 1016 & 5.6 & 2736 & 3.9 & 2820 & 2.2 & 4830 & 5.7 \\
\hline & Annual Total & 70940 & & 35136 & & 121160 & & 107391 & & 163920 & \\
\hline & Index & & 189 & & 193 & & 175 & & 85 & & 192 \\
\hline
\end{tabular}




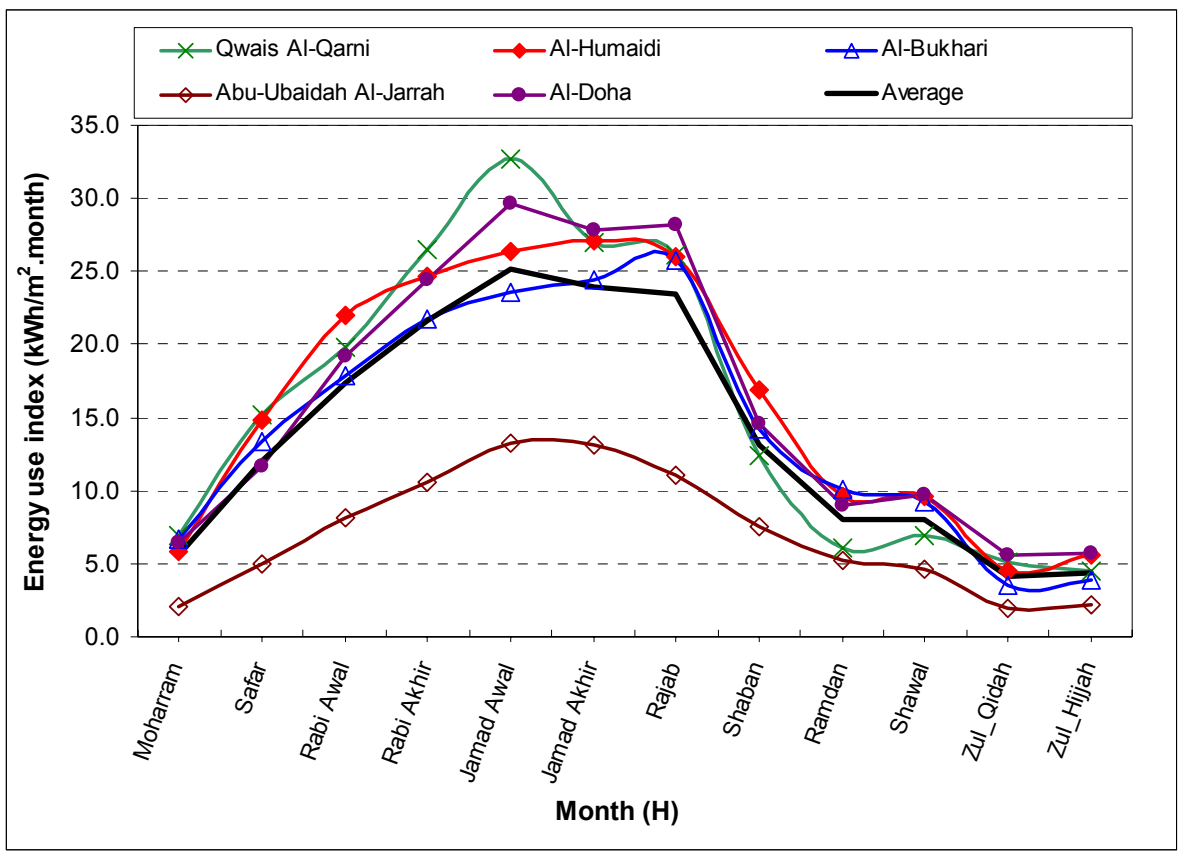

Fig. 3: Energy use indices for the five mosques averaged over five-year (1419-1423 H) billing data. The 5-mosque average is highlighted in bold.

\section{Electric Energy Billing Data Conversion}

In order to match electric energy bills data with the seasonal climatic variations, the monthly data had to be presented according to the solar (Gregorian) calendar. This was achieved by finding the solar (Gregorian) months/years corresponding to those with reported data in lunar (Hijri) months. The average daily electric energy use was then calculated by dividing the lunar (Hijri) monthly energy use value by the number of days per that month. The Gregorian monthly value was then calculated by summing the average daily values for those days of Hijri months corresponding to the Gregorian month. Due to the fact that the time of the month of meter readings is not known, the analyses were made considering two scenarios for the actual time of recording the reported monthly readings: at the middle of the Hijri month and at the end of the Hijri month. However, after examining the obtained monthly values it was observed that the assumption that readings were taken at the middle of the Hijri month is more reasonable where it revealed peak energy use in the expected summer months of August and/or September for each year for all investigated mosques. Fig. 4. shows an example illustrating the procedure for Hijri-Gregorian energy bill conversions. 


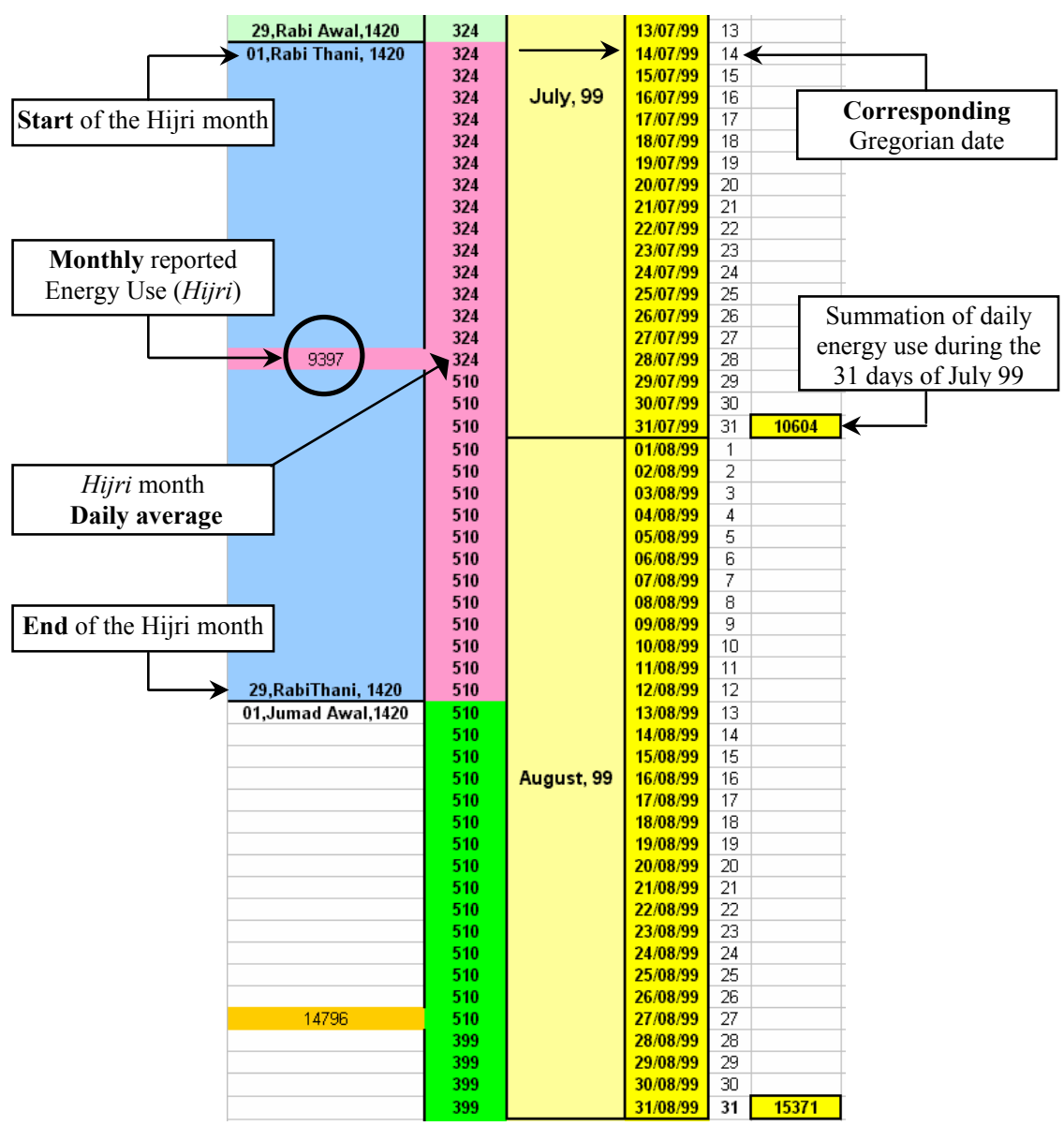

Fig. 4: An example illustrating the procedure for converting energy bills from the Hijri to Gregorian calendar

Fig. 5(a) illustrates an example of the electric energy use for Abu-Ubaidah mosque as obtained from the energy bills recorded for five Hijri years. The corresponding converted Gregorian energy use is shown in Fig. 5(b) Examining the presented data of Fig. 5(a) shows the inconsistency in energy use profiles over the years with different months of peak energy use for the different years. This is expected due to the shift in the correspondence of the Hijri months by about 11 days from the Gregorian calendar every year. This shift normally results in mismatching between the time of the year and the prevailing weather conditions from one year to the other. However, when the data was converted to solar (Gregorian) calendar months, a more smooth energy use profile was obtained over time with a common peak energy use in August and a reasonable match with the average of the five years as presented in Fig. 5(b). 

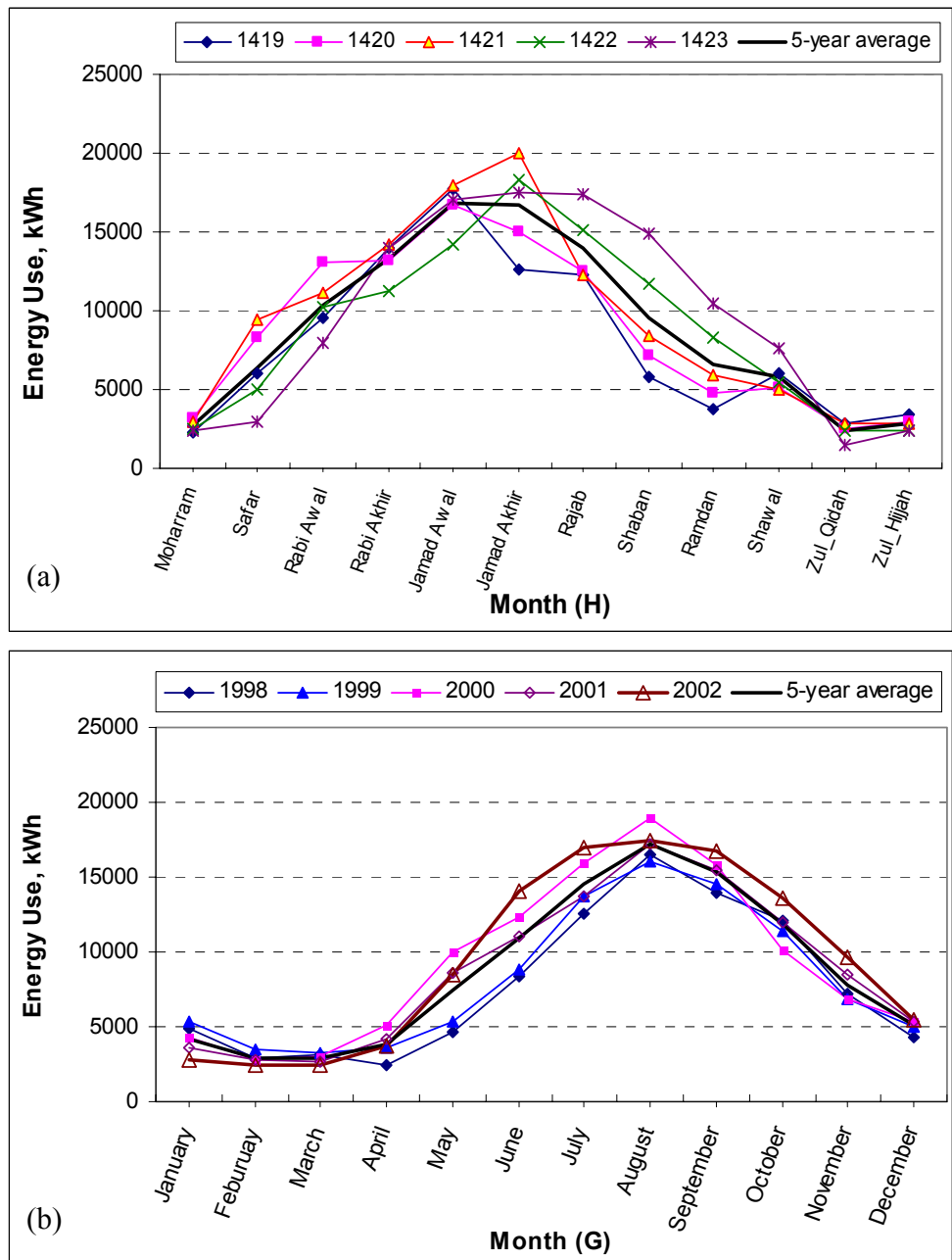

Fig. 5: Abu-Ubaidah mosque monthly billing electric energy use profiles (a) Hijri energy bills data (b) Corresponding converted Gregorian energy bills data.

The same procedure was followed in converting electric energy use data from lunar (Hijri) calendar to solar (Gregorian) calendar for all other mosques. A close look at the data comparison of the converted monthly total energy use for the five mosques averaged over the five-year billing period (1988-2002G) shown in Fig. 6(a) reveals that although the annual energy use trend is similar for all mosques, there are large variations in the magnitude of energy use from one mosque to the other. This is expected, as no two mosques of those presented are similar either in size, energy system type or in use patterns. The scale of total energy use is expected to be proportional to the mosque size with 
the larger mosques using more energy. However, this is not true for all mosques as energy use of Abu-Ubaidah mosque is close to the average of all mosques even though it is the largest of all in size. This low energy use is also observed in the energy use index analysis for this mosque as presented earlier.
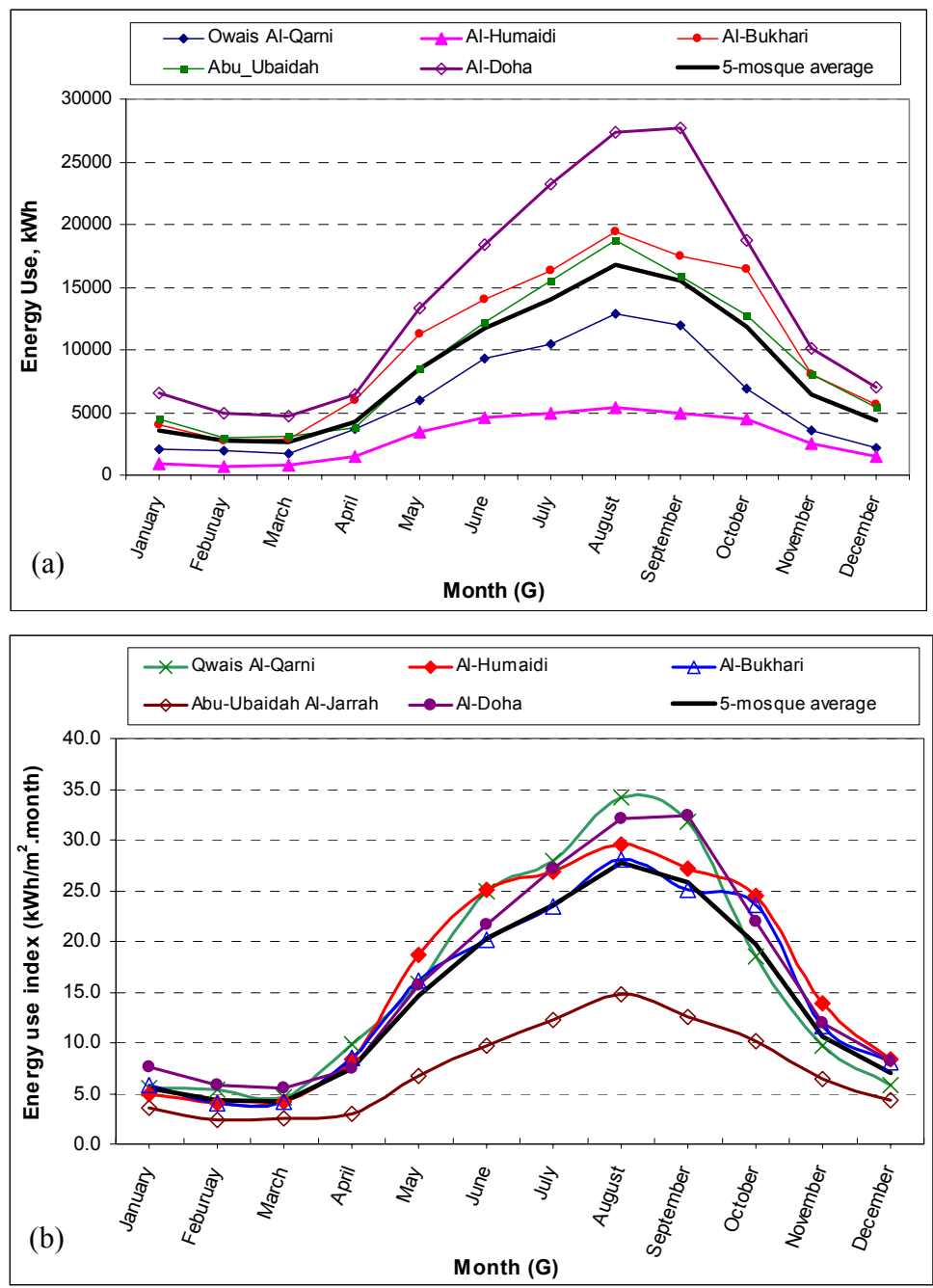

Fig. 6: (a) Monthly total energy use and (b) Monthly energy use indices for the five mosques averaged over five-year billing period (1988-2002G) based on HijriGregorian energy bills converted data.

The five-year average annual total energy use and annual energy use indices based on the reported lunar (Hijri) and converted solar (Gregorian) months are summarized in Table 5 for the five mosques. Comparison of the two sets of data 
before and after conversion shows a very close agreement for all mosques under investigation. The percentage differences are between $1 \%$ and $3.5 \%$ with an average difference of $2.4 \%$ in the annual average energy use index of the five mosques. This gives confidence in the data conversion procedure which proved consistent for all five mosques.

Table 5: Five-year annual energy lunar vs. converted solar calendar billing data comparison

\begin{tabular}{|c|c|c|c|c|c|}
\hline \multirow[b]{3}{*}{ Mosque Name } & \multicolumn{4}{|c|}{ Five-Years Annual Energy Billing Data Average } & \multirow[b]{3}{*}{$\begin{array}{c}\text { Difference } \\
\%\end{array}$} \\
\hline & \multicolumn{2}{|c|}{ Annual total, kWh } & \multicolumn{2}{|c|}{ Annual energy use index, $\mathrm{Kwh} / \mathrm{m}^{2}$} & \\
\hline & $\begin{array}{c}\text { Lunar } \\
\text { Calendar } \\
(\text { Hijri })\end{array}$ & $\begin{array}{c}\text { Solar } \\
\text { Calendar } \\
\text { (Gregorian) }\end{array}$ & $\begin{array}{c}\text { Lunar } \\
\text { Calendar } \\
(\text { Hijri })\end{array}$ & $\begin{array}{c}\text { Solar } \\
\text { Calendar } \\
\text { (Gregorian) }\end{array}$ & \\
\hline Owais Al-Qarni & 70940 & 72721 & 189 & 194 & $+2.6 \%$ \\
\hline Al-Humaidi & 35136 & 35559 & 193 & 195 & $+1.0 \%$ \\
\hline Al-Bukhari & 121160 & 124213 & 175 & 179 & $+2.3 \%$ \\
\hline Abu-Ubaidah & 107391 & 111431 & 85 & 88 & $+3.5 \%$ \\
\hline Al-Doha & 163920 & 168603 & 192 & 197 & $+2.6 \%$ \\
\hline & & Average & 167 & 171 & $+2.4 \%$ \\
\hline
\end{tabular}

Due to the large variations in the physical and operational characteristics of the mosques as well as variations in mosque sizes and the energy system used in each mosque, the billing data cannot be directly used as the basis for comparing annual energy uses of the different mosques. Instead, the utilization of an annual energy use index per unit area $\left(\mathrm{kWh} / \mathrm{m}^{2} . \mathrm{yr}\right)$ was found to be the best reference for analysis. This helps overcome and/or minimize the inaccuracy resulting from the inconsistency in meter reading intervals as well as the possible errors resulting from the lunar-solar calendar conversions. Therefore, the annual energy use index per unit area can be used for comparison between different mosques.

The five-year monthly average energy use indices for the five mosques are shown in Fig. 6 for the purpose of comparison among the different mosques. The five-year average energy use indices for the five mosques are shown in Fig. 6 . The presented data shows average energy use indices of 189, 193, 175, 85, and $192 \mathrm{kWh} / \mathrm{m}^{2}$.yr for Owais Al-Qarni, Al-Humaidi, Al-Bukhari AbuUbaidah, and Al-Doha mosques, respectively. The average annual energy use index of the five mosques is $167 \mathrm{kWh} / \mathrm{m}^{2}$.yr. On excluding Abu-Ubaidah's mosque with its low energy use index, the analysis reveals an annual average 
energy use index of $187.3 \mathrm{kWh} / \mathrm{m}^{2}$.yr for the other four mosques. This makes them within a $9 \%$ range. The low energy use index of $85 \mathrm{kWh} / \mathrm{m}^{2}$.yr for AbuUbaidah mosque is $54.6 \%$ less than the average of the other four mosques and can be attributed to a number of reasons. The main reason is its new insulated construction as it is the only insulated mosque among the presented group. In addition, there is its low occupancy in relation to its size as a Friday mosque which results in the use of small portion of the mosque and consequently the operation of only the $\mathrm{A} / \mathrm{C}$ units serving this limited occupancy during daily prayer times.

The next lowest annual energy use index of $175 \mathrm{kWh} / \mathrm{m}^{2} . \mathrm{yr}$ is for AlBukhari mosque. This mosque is characterized by having a thermal zone for daily prayers separated from the main Friday prayer hall. This thermal zoning limits the air-conditioning operation during daily prayers to the occupied zone only without the need to air-condition the whole volume of the mosque as is the case in many others. This strategy would be expected to produce a lower energy use index.

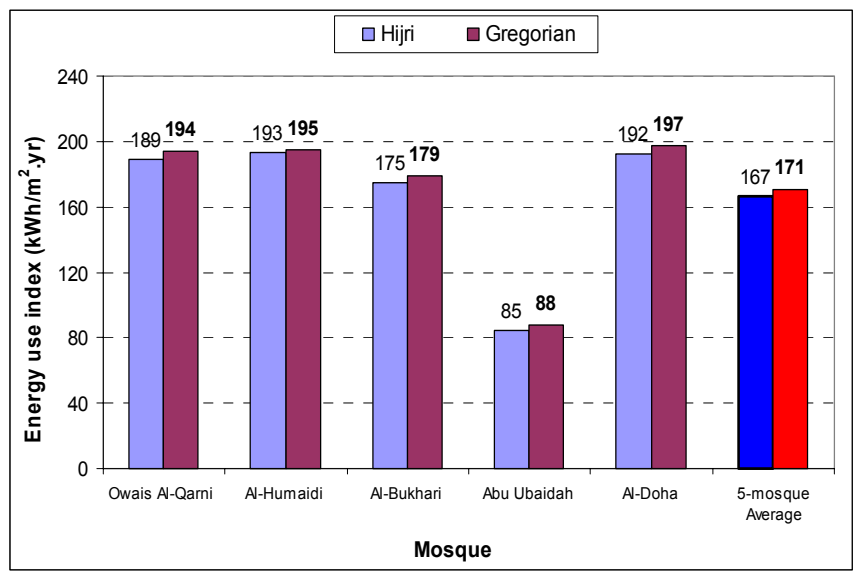

Fig. 7: Five-year average of electric energy use indices based on Hijri energy bills data and Hijri-Gregorian energy bills converted data. The 5-mosque averages are also shown.

\section{Conclusions}

This study presented the analysis of electric energy data for selected typical mosques in the hot-humid climate of the eastern region of Saudi Arabia. The criteria for mosque categorization and selection were presented. The approach for overcoming the difficulties in the reporting periods of the energy use data was described. The process of converting data from lunar (Hijri) calendar to solar (Gregorian) calendar was also presented. The completed converted data showed reliable results which matched the expected peaks in the months of 
summer as well as the yearly expected energy use trends in all investigated mosques. It is hoped that the methodology presented will be of use in the analysis of similar data for the same or other types of buildings.

The analyses of the electric energy bills data presented are useful in showing the general trend and the history of energy use for those mosques. The billing data can provide a reasonable estimate of the overall annual electric energy use for each mosque. However, the billing data is not an accurate reference for comparison of different mosques on a Hijri monthly basis as commonly reported by the Saudi Electric Company. This is due to the inconsistency in meter readings among the different mosques for the same month and also for the different months of the year for the same mosque. This problem would be aggravated by the use of the lunar (Hijri) calendar, which does not serve in consistently matching energy use with climatic conditions over the years, as the basis for reporting the data without reference to the corresponding solar (Gregorian) calendar. Therefore, to get reasonable data analyses, an effort is required to present the data in a more usable format serving the purpose of the analysis as presented earlier. Yet, electric energy billing data does not provide the necessary segregated energy end uses by the various energy systems for the purposes of detailed mosque energy analysis. Supplementary analysis of detailed energy data as obtained from monitoring will provide more useful information on the energy end use and the potential design and operational strategies for achieving the desired thermal comfort with the lowest energy requirements. This level of analysis is currently the subject of ongoing investigation.

\section{Acknowledgment}

This paper is part of project grant no. AT-13-18 funded by King Abdul-Aziz City for Science and Technology (KACST), Saudi Arabia. The financial support of $K A C S T$ as well as the support and facilities provided by KFUPM are highly appreciated.

\section{References}

[1] Electrical Affairs Agency (EAA), Electricity Growth and Development in the Kingdom of Saudi Arabia, Ministry of Industry and Electricity, Riyadh, Saudi Arabia (2002).

[2] Said, S. A. and M. A. Abdelrahman, Energy Efficiency of a Building in the Eastern Province of Saudi Arabia: Parametric Analysis with DOE 2.1A, ASHRAE Transactions. Vol. 95, pp. 147-152 (1989).

[3] Al-Homoud, M. S., Optimum Thermal Design of Air-Conditioned Residential Buildings, Building and Environment, Vol. 32, No. 3, pp. 203-210 (1997).

[4] Al-Homoud, M. S. Optimum Thermal Design of Office Buildings, International Journal of Energy Research, Vol. 21, pp. 941-957 (1997).

[5] Ismail Sergeld and James Steele (Editors), Architecture of the Contemporary Mosque, Academy Group Ltd. (1996). 
[6] Ibrahim H. M., Planning Standards for Mosques (in Arabic Language) Ministry of Municipal \& Rural Affairs, Kingdom of Saudi Arabia (1979).

[7] Ministry of Islamic Affairs, Endowments, Da 'wah and Guidance (MIAEDG)

[8] Thuamann, Albert, fourth edition, Handbook of Energy Audits, the Fairmont Press, Lilburn, GA. (1995).

[9] Abdou, A. A., M. S. Al-Homoud, and I. M. Budaiwi, A Systematic Approach for Energy Audit in Mosques, Proc. $2^{\text {nd }}$ International Conference on Energy Research and Development, Kuwait University, Kuwait, Vol. 1, pp. 77-86, May 8-10 (2002). 


\section{أداء الطلةة في المسلجد \\ الجزء الأول: معاينة لستخدلملت الطاقة بناءً على تحليل بيانات فوالتير لستهلاك الكهرباء}

علال عبد المنعم عبه, محمد بنسعد ل حمود , إلسماعلل بن محمد بليوي

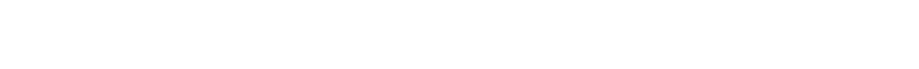
الظهران، المملكة العربية للسعوية المعاية

المستخلص: تتميز المسلجد عن أنواع المباني الأخرى بوظفيفتا الفريبة

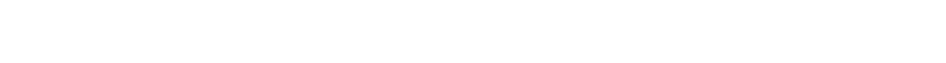

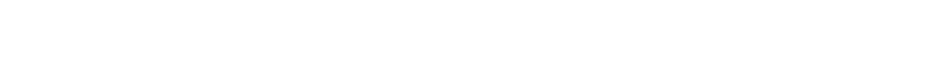

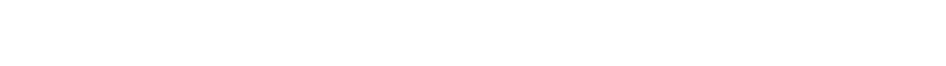
الاعتماد فيها على الوسالل الميكانيكية للتبريد أو للتذفئة لتحقيق الرلحة

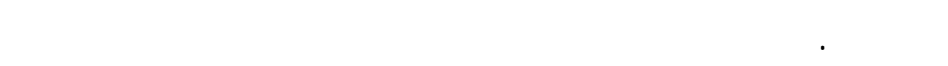

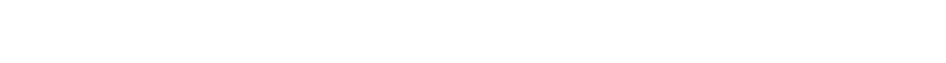

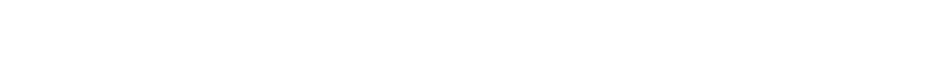

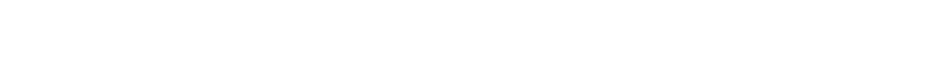

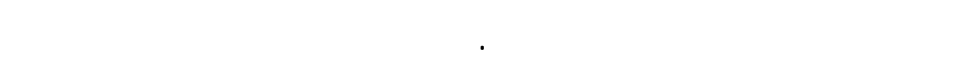

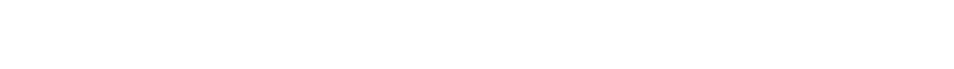

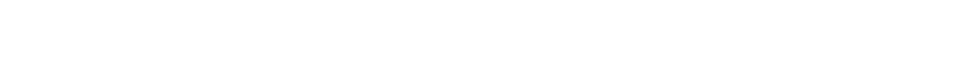

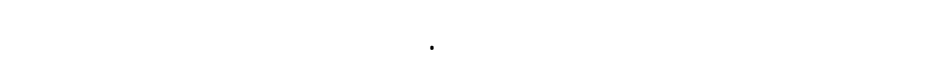

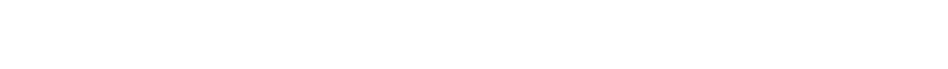


لخمسة مسلجد نمونجية في المناخ الحار الرطب للمطقة الشرقية

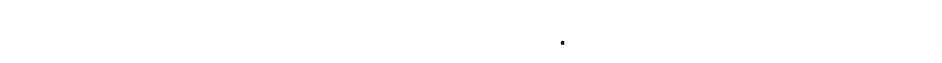

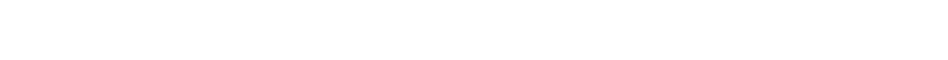
شالملة لأظمة الطاقة والأداء الحراري ولستراتيجيت تشغيل أظظمة تكييف الهواء في المسلجد. 